\title{
Behaviour of settlement-stage larvae of fishes with an estuarine juvenile phase: in situ observations in a warm-temperate estuary
}

\author{
Thomas Trnski* \\ Ichthyology, Division of Vertebrate Zoology, Australian Museum, 6 College Street, Sydney, New South Wales 2010, \\ and Department of Environmental Sciences, University of Technology, PO Box 123, Broadway, Sydney, \\ New South Wales 2007, Australia
}

\begin{abstract}
Observations of behaviour were made on a total of 103 settlement-stage larvae (9 to $15 \mathrm{~mm}$ standard length [SL]) of 4 species of estuary-dependent fishes in Lake Macquarie, a barrier estuary on the central coast of New South Wales, Australia. Larvae were released at mid-depth over deep water or within sight of settlement habitat, and their behaviour was observed by SCUBA divers. Average near-surface swimming speed was $6.4 \mathrm{~cm} \mathrm{~s}^{-1}$ (7.1 body lengths [BL] s${ }^{-1}$ ) for Acanthopagrus australis, $6.4 \mathrm{~cm} \mathrm{~s}^{-1}\left(6.5 \mathrm{BL} \mathrm{s}^{-1}\right)$ for Rhabdosargus sarba, $10.9 \mathrm{~cm} \mathrm{~s}^{-1}\left(10.8 \mathrm{BL} \mathrm{s}^{-1}\right)$ for Pagrus auratus (all family Sparidae) and $12.5 \mathrm{~cm} \mathrm{~s}^{-1}\left(11.2 \mathrm{BL} \mathrm{s}^{-1}\right.$ ) for Girella tricuspidata (Girellidae). These speeds were faster than previously recorded for temperate fish larvae. It is hypothesised that body morphology determines swimming ability. At these speeds, the larvae are faster than ambient currents. The majority of larvae of all species swam in a directional (non-random) manner, but there was no evidence that the larvae were orienting to the shoreline or the sun. There were species-specific differences in depth profile: the 3 species that settle in seagrass beds preferentially swam near the surface; $P$. auratus, which settles over soft bottoms, preferentially swam to the bottom. Swimming near the surface in Lake Macquarie brings larvae into strong wind-driven surface currents that carry them to a shoreline and settlement habitat. Larvae of only G. tricuspidata (1 of 3 species that settle in seagrass) were rarely observed to settle when they were released within sight of a seagrass margin.
\end{abstract}

KEY WORDS: Larva - Fish · Behaviour · Swimming speed - Settlement - Orientation · Acanthopagrus · Girella $\cdot$ Pagrus $\cdot$ Rhabdosargus

Resale or republication not permitted without written consent of the publisher

\section{INTRODUCTION}

Some fishes that spawn in coastal marine waters exclusively use estuaries as juvenile nurseries. Many estuary-dependent fishes rely on currents to transport eggs and larvae from a marine spawning site to an estuarine nursery (Able \& Fahay 1998, Werner et al. 1999). Advection by currents is largely responsible for transport of the eggs and early larvae (Power 1984). As the larvae develop, their behavioural and sensory abilities increase, and appropriate responses to physical cues can enhance transport to an estuary (Forward et

*Correspondence address. E-mail: tomt@austmus.gov.au al. 1999, Tolimieri et al. 2000). Models that incorporate larval behaviour are thus increasingly important to understand migration in late-stage larvae (Wolanski et al. 1997, Armsworth 2000).

To enter an estuary, larvae may rely on large-scale displacement by major currents (Jenkins \& Black 1994, Jenkins et al. 1997, 1999), or use selective tidal stream transport (Forward et al. 1999). Once in the estuary, they require a high level of behavioural ability to find and settle in a suitable habitat (Breitberg et al. 1995). It is clear from recent studies on the behavioural abilities of late-stage larvae of coral reef fishes that they are strong, enduring swimmers (Stobutzki \& Bellwood 1994, Leis \& Carson-Ewart 1997). If late-stage larvae of temperate estuary-dependent fishes can swim at com- 


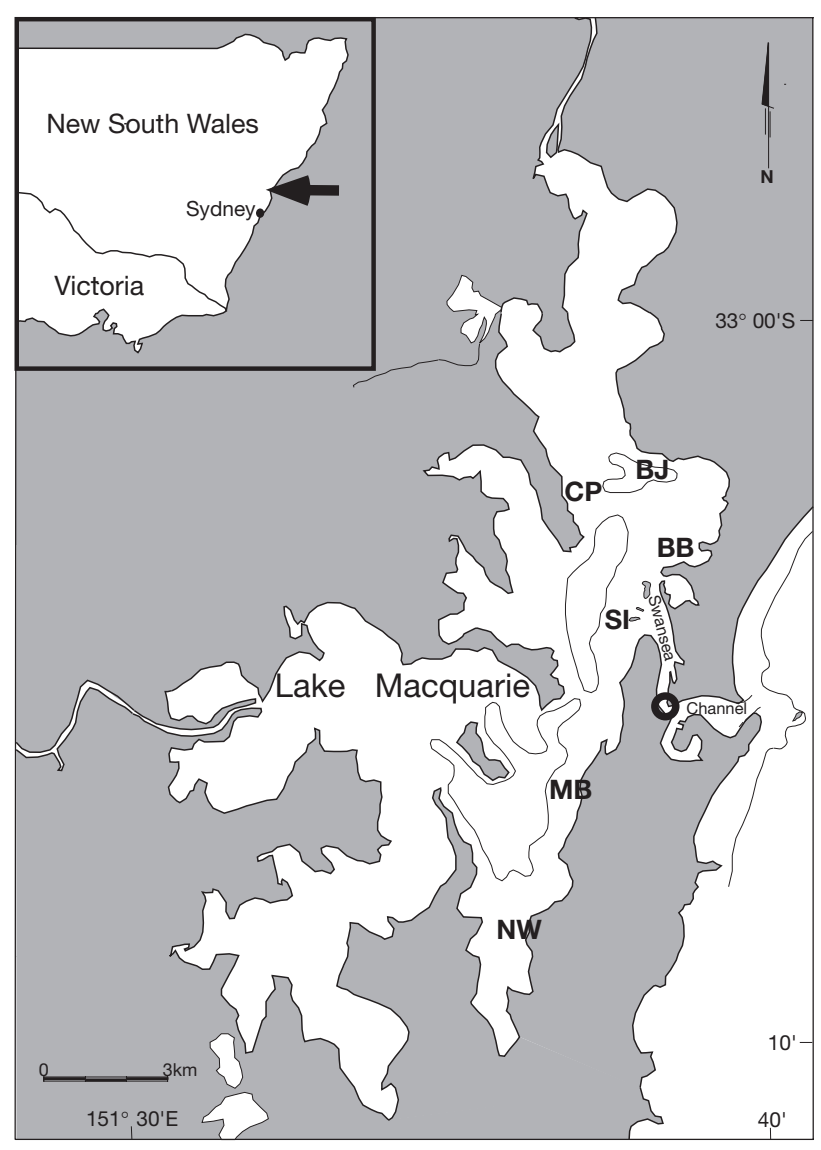

Fig. 1. Lake Macquarie and release sites. See Table 1 for site codes. Thin lines: $10 \mathrm{~m}$ depth; open circle: collection site

parable speeds they could maintain themselves in estuarine plumes and swim to nursery habitats, even if they were unable to overcome tidal currents in an estuarine channel. In contrast to tropical fishes, larvae of temperate northern hemisphere fishes are weak swimmers (Blaxter 1986, Miller et al. 1988). Similarly, the swimming speeds of settlement-size sparids from Japan were relatively slow at about 2 to $3 \mathrm{BL} \mathrm{s}^{-1}$ (Fukuhara 1985, 1987). Yet 13 mm SL Trachurus larvae in New Zealand sustained swimming speeds of up to $10 \mathrm{BL} \mathrm{s}^{-1}$ (Dudley et al. 2000); this is the first record of fast swimming in temperate fish larvae. In part the differences in reported swimming speeds between tropical and temperate fishes may be due to water temperature (Wardle 1975, Wieser \& Kaufman 1998), and differences in methodology (reared vs wild larvae, and laboratory vs in situ observations; reviewed in Leis \& Carson-Ewart 1997). However, much of the variation is probably due to taxonomic and morphological differences (Leis \& Carson-Ewart 1997, Stobutzki \& Bellwood 1997, Stobutzki 1998, Dudley et al. 2000, Leis \& McCormick 2002).
Late-stage larvae of coral-reef fishes display complex orientation behaviour that varies diurnally and with proximity to the reef (Leis et al. 1996, Leis \& Carson-Ewart 1998, 1999, Stobutzki \& Bellwood 1998). To date, similar observations in temperate waters have been made only on pelagic crab and lobster larvae (Shanks 1985 and references therein, Shanks 1995).

The swimming and orientation abilities of estuarydependent fishes approaching settlement are unknown. These abilities largely determine the success and location of settlement. I examined the behaviour of 4 species of fish larvae that spawn in coastal marine waters and use estuaries as juvenile nurseries. This paper reports on the behaviour of late-stage larvae that are competent to settle. The larvae were released in an estuary where juveniles of all 4 species occur, to examine their swimming capabilities, and to determine whether they have a vertical preference in the water column or show any evidence of compass directionality. An additional aim was to examine whether behaviour differed when larvae were released over deep water or within sight of potential settlement habitat. The results were further related to the current regime in the estuary and subsequent implications for dispersal in the estuary.

\section{MATERIALS AND METHODS}

Study site. Lake Macquarie is a large barrier estuary on the central coast of New South Wales, Australia (Fig. 1). It has a surface area of approximately $120 \mathrm{~km}^{2}$ and a maximum and mean depth of 11 and $7 \mathrm{~m}$, respectively (MHL 1996). The estuary is predominantly marine in character, with mean annual surface salinity ranging from 28.6 to 35.4 (AWACS 1995). Deeper parts of the lake are mostly soft mud, and shallow sectors are sand (Roy \& Peat 1975). A total of approximately $14 \mathrm{~km}^{2}$ of seagrass occurs along the margins of Lake Macquarie, dominated by Zostera capricorni plus several large stands of Posidonia australis near the junction with Swansea Channel (King 1986).

Swansea Channel connects Lake Macquarie with coastal waters (Fig. 1). The channel is approximately $5 \mathrm{~km}$ long, varies in width from 100 to $400 \mathrm{~m}$ and is generally 2 to $5 \mathrm{~m}$ deep, with deeper sections (>8 m) restricted to areas near Swansea Bridge (WA 1998). Flow through the channel into and out of Lake Macquarie is almost entirely tidally driven, the exceptions being during periods of heavy rain and persistent strong winds. Tides are semi-diurnal and the tidal range in the area is about $2.0 \mathrm{~m}$. Water velocities in the channel reach a maximum of about $2 \mathrm{~m} \mathrm{~s}^{-1}$, and current, salinity and temperature are all vertically unstratified (MHL 1996). 
Current measurements. Surface currents in Lake Macquarie, over deep water north and west of the junction with Swansea Channel, were quantified using a cylindrical drogue constructed of $1 \mathrm{~mm}$ mesh PVC shade cloth, $300 \mathrm{~mm}$ high and $300 \mathrm{~mm}$ in diameter. Currents in Lake Macquarie were measured on 7 to 9 and 11 September 1999. The drogue was set $0.3 \mathrm{~m}$ below the surface and tracked for approximately $1 \mathrm{~h}$. Start and end positions of the drogue were estimated with a geographic positioning system (GPS). Wind speeds were recorded $30 \mathrm{~min}$ before and every $10 \mathrm{~min}$ utes during drogue deployment from an anonometer on the eastern bank of Swansea Channel, approximately $1 \mathrm{~km}$ ESE of Spectacle Island (SI in Fig. 1).

Sampling. Fish larvae were collected in surface waters of Swansea Channel in a channel net during morning flood tides. The net was attached to the base of Swansea Bridge (depth $10 \mathrm{~m}$ ) with a $30 \mathrm{~m}$ anchor rope. The $2 \mathrm{~m}^{2}$ net mouth was attached to the anchor rope with a 4-point bridle of stainless steel cables. Foam buoys supported the net frame, and the net fished from the surface to a depth of $1.1 \mathrm{~m}$. Mesh size was approximately $1 \mathrm{~mm}$.

Collections and releases were made from 12 July to 25 August 1998 and 29 August to 16 September 1999. Time of collections ranged from 07:00 to 13:00 h. The contents of the codend were emptied every 10 min into a tray with seawater. Live settlement-stage larvae of the 4 target species were removed from the tray with a hand net and placed in a 31 aerated holding bucket filled with seawater. At least $50 \%$ of the water in the holding bucket was replaced hourly.

Larvae were released at 6 sites with various shore orientations around Lake Macquarie (Table 1, Fig. 1) within 2 to $8 \mathrm{~h}$ of capture, and always during daylight. Surface salinity and temperature were recorded at each release site in 1998 only. For behavioural observations over deep water ( 7.2 to $10.1 \mathrm{~m}$ ), larvae were released at approximately mid-depth, at which the bottom (dark mud without vegetation) was usually not visible to the divers. For observations over shallow water (2.8 to $4.5 \mathrm{~m}$ ) larvae were released at approximately middepth, at which the bottom was always clearly visible to the divers. Larvae were released over sparse Zostera seagrass interspersed with patches of mud and sand at Murrays Beach and Nords Wharf. At Belmont Bay and Spectacle Island larvae were released directly over sand within sight of a margin of dense Posidonia. The margin graded from clean sand to a narrow band of sparse Zostera (up to $0.5 \mathrm{~m}$ wide), to a narrow band of mixed Zostera and sparse Posidonia (up to $0.5 \mathrm{~m}$ wide), and then to dense Posidonia. At Spectacle Island the margin was a depth-associated limit of growth of Posidonia, while at Belmont Bay there were large patches of sand ( 2 to $10 \mathrm{~m}$ in size) within dense Posidonia beds.
Larvae were released and observations were made using the technique of Leis et al. (1996) and Leis \& Carson-Ewart (1997), with 2 divers who were 2 to $4 \mathrm{~m}$ apart at the time of release of larvae and alternated their horizontal orientation to reduce potential bias in initial swimming direction of the larvae. The diver acting as observer released individual larvae from a small translucent container in mid-water and followed 0.6 to $2 \mathrm{~m}$ behind the larva, remaining as far away as visibility would allow. Distance travelled by, and average speed of, each larva was estimated using a flow meter with a low-speed rotor (Leis \& Carson-Ewart 1997), calibrated over a $20 \mathrm{~m}$ course at speeds of 3, 6, 12 and $20 \mathrm{~cm} \mathrm{~s}^{-1}$. A regression equation $\left(\mathrm{R}^{2}=0.96\right)$ was used to estimate distance travelled. The larvae were followed for $10 \mathrm{~min}$ unless the observer lost sight of them. In 1999, some observations were terminated after a minimum of $5 \mathrm{~min}$, either because the larva settled at a site, or because it was cruising at a constant depth and direction for at least 2 min (previous observations indicated that larvae that stabilised their vertical and horizontal orientation within 5 min maintained a relatively constant depth and direction for the remainder of 10 min observations). Direction was estimated with an analogue compass to the nearest $10^{\circ}$, and is reported in degrees magnetic which differs from true north by $12^{\circ} 25^{\prime}$ in the area. Larvae that were recaptured after observations were complete were fixed in $80 \%$ ethanol and subsequently identified and measured. The support boat remained anchored to avoid motor noise from influencing larval behaviour.

Study species. Four species were released: 3 sparids (Acanthopagrus australis, Pagrus auratus and Rhabdosargus sarba) and a girellid (Girella tricuspidata). These 4 species were selected for study, because they are commercially important and they all settle in juvenile habitat at a similar time. All spawn in coastal marine waters. A. australis, R. sarba and G. tricuspidata depend on estuarine seagrass beds during their early juvenile stage, and $A$. australis also uses submerged mangrove roots and pneumatophores (SPCC 1981, Laegdsgaard \& Johnson 1995, Hannan \& Williams 1998). $P$. auratus appears to settle over mud, in large estuaries and bays (SPCC 1981, Hamer et al. 1998), and also in sheltered marine waters (Francis 1995). The species are distinguishable macroscopically except for $A$. australis and $R$. sarba, which are distinguishable only by microscopic examination. Only individuals of $A$. australis and $R$. sarba that were recaptured could be identified reliably. Larvae of these 2 species that were not recaptured following the observations were classified as ' $A$. australis OR $R$. sarba'. 'A. australis AND $R$. sarba' refers to the combination of recaptured and non-recaptured larvae of the 2 species. 


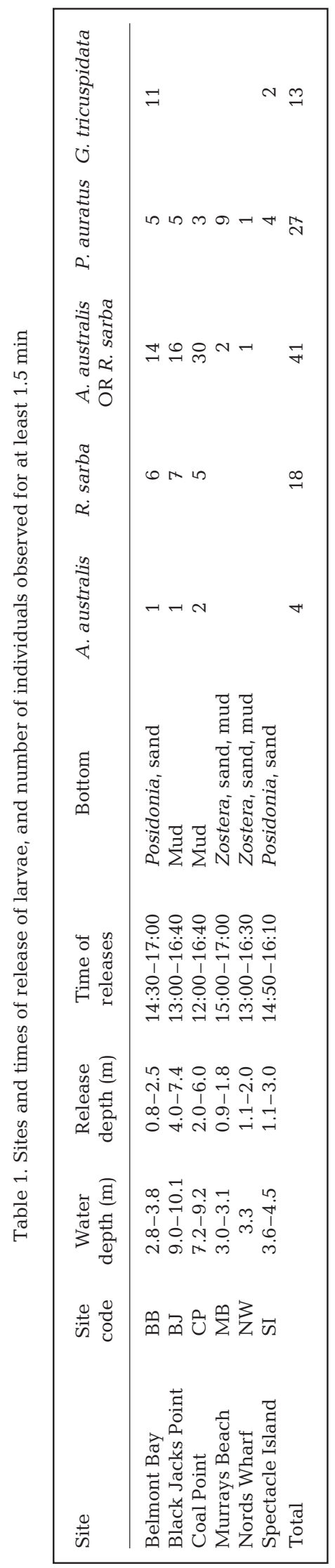

The fishes used for this study were all considered larvae, following the definition of Leis \& Carson-Ewart (2000). All 4 species settle abruptly in their nursery habitat, after which time they are considered juveniles. At the time of capture they had not yet settled. All larvae released for this study were considered to be competent to settle, based on the identical size and morphological development of recently settled juveniles in shallow seagrass in Lake Macquarie (T. Trnski unpubl. data). Pagrus auratus were rarely collected in seagrass. Larvae of $P$. auratus from $9.0 \mathrm{~mm}$ SL were considered competent to settle because they had full fin complements, were fully scaled, had juvenile pigmentation and almost always rapidly settled after release; the closely related $P$. major from Japan settles at $10 \mathrm{~mm}$ fork length (Azeta et al. 1980). The size range of released larvae subsequently captured and after fixation was 9.6 to $11.1 \mathrm{~mm}$ SL $(\mathrm{n}=7)$ for Acanthopagrus australis (which settle at 8 to $11 \mathrm{~mm}$, unpubl. data); 10.2 to $15.0 \mathrm{~mm} \mathrm{SL}(\mathrm{n}=8)$ for $P$. auratus (settlement size assumed to be from $9.0 \mathrm{~mm} \mathrm{SL}$ ); 9.3 to $11.4 \mathrm{~mm} \mathrm{SL}$ ( $\mathrm{n}=20$ ) for Rhabdosargus sarba (which settle at 8 to $12 \mathrm{~mm})$; and 11.6 to $11.7 \mathrm{~mm}(\mathrm{n}=2)$ for Girella tricuspidata (which settle at 9 to $13.5 \mathrm{~mm}$ ).

Data analysis. Observations of short duration (due to lost or injured fish larvae) were excluded from the analysis. Observations with a minimum of 6 data readings ( $3 \mathrm{~min}$ ) for each larva were used to estimate swimming speed and describe orientation, while larvae with a minimum of 3 data readings ( $1.5 \mathrm{~min}$ ) were used to describe depth distribution. Swimming speeds are given in $\mathrm{cm} \mathrm{s}^{-1}$ and BL s${ }^{-1}$. Body length (BL) was estimated from larvae collected concurrently with this study during flood tides at night in Swansea Channel. The mean size of Acanthopagrus australis larvae collected was $9.0 \mathrm{~mm}$ SL ( $=889)$, Rhabdosargus sarba 9.9 mm ( $\mathrm{n}=2599)$, Pagrus auratus $10.1 \mathrm{~mm}(\mathrm{n}=519)$ and Girella tricuspidata $11.2 \mathrm{~mm}(\mathrm{n}=972)$. These mean values were used as estimates of body length of released larvae. Larvae of 'A. australis OR R. sarba' that were not recaptured were assumed to have an average body length of $9.5 \mathrm{~mm}$. Speed of larvae swimming at different depths (surface, middle or bottom) were pooled among sites and analysed using a Kolmogorov-Smirnov goodness of fit test (Zar 1996).

Directional orientation of individual larvae at all sites was tested using Rayleigh's test for circular uniformity (Batschelet 1981, Zar 1996) to determine whether larvae swam randomly or directionally during the observations. To test whether larvae orient to the shoreline or sun, orientation was analysed only at the 2 deep stations (Black Jacks Point and Coal Point) where no benthic orientation cues were visible at time of release. The adjacent shoreline at these sites is located at a bearing of $10^{\circ}$ from the release site at Black Jacks 
Point, and $250^{\circ}$ at Coal Point. Swimming direction of larvae at these 2 sites was pooled by standardising directions, where $0^{\circ}$ is directly towards the shore or the sun. Data on individual larvae that swam directionally with 19 or 20 direction records (9.5 to $10 \mathrm{~min}$ ) were reduced to a mean angle and vector. A 2nd-order analysis of these mean angles and vectors was undertaken using Moore's non-parametric test (Batschelet 1981).

\section{RESULTS}

\section{Physical variables}

Surface salinity and temperature at the 1998 release sites varied from 25.0 to 33.0 , and 14.1 to $16.2^{\circ} \mathrm{C}$, respectively. Turbidity was variable depending on rainfall and wind intensity. Visibility ranged from 1 to $5 \mathrm{~m}$. Tidal currents in Lake Macquarie are negligible $\left(<0.2 \mathrm{~cm} \mathrm{~s}^{-1}\right)$ and models indicate that surface currents are proportional to wind speed and flow is in the direction of the wind, with a weaker counter-current near the bottom (AWACS 1995). Average wind speeds of 3.5 to $7.7 \mathrm{~m} \mathrm{~s}^{-1}$ generated surface $(0.3 \mathrm{~m}$ depth) currents of 13 to $26 \mathrm{~cm} \mathrm{~s}^{-1}$.

\section{Behaviour of larvae at release and during observations}

A total of 103 larvae were released and followed for a minimum of $1.5 \mathrm{~min}$ (Table 1), and of these, 82 were followed for a minimum of $3 \mathrm{~min}$ (Table 2). Of 63 Acanthopagrus australis and Rhabdosargus sarba, 4 and 18, respectively, were recaptured and identified.

Individual larvae were often startled upon release, with a burst of swimming that usually lasted less than $30 \mathrm{~s}$, and always less than $1 \mathrm{~min}$. Most of the unrecorded releases were lost during this burst swimming, especially if there was a rapid ascent or descent involved. After this initial burst of swimming, larvae settled into a cruise-swimming pattern with stable (or less erratic) speed and vertical and horizontal orientation. During cruise swimming, larvae were observed feeding, searching (for food?), avoiding apparent predators (ctenophores, cnidarians and large mucous strands) and defaecating. Some larvae swimming near the surface were observed orienting toward (usually swimming under) surface features such as bubbles and floating debris for short periods of time (up to 10 s of seconds). A single Acantho- pagrus australis OR Rhabdosargus sarba larva swam along a floating length of rope for approximately 1 min and then swam away from it.

\section{Swimming speed}

Average swimming speed varied among species (Fig. 2). Average speed of surface- and midwaterswimmers ranged from 6.4 to $12.5 \mathrm{~cm} \mathrm{~s}^{-1}$, depending on species. This is equivalent to an average speed of 7.1 $\mathrm{BL} \mathrm{s}^{-1}$ for Acanthopagrus australis larvae, 6.5 BL s${ }^{-1}$ for Rhabdosargus sarba, $7.8 \mathrm{BL} \mathrm{s}^{-1}$ for A. australis OR R. sarba, 10.8 $\mathrm{BL} \mathrm{s}^{-1}$ for Pagrus auratus and 11.2 $\mathrm{BL} \mathrm{s}^{-1}$ for Girella tricuspidata. There was no difference in speed between $A$. australis and $R$. sarba larvae (Kolmogorov-Smirnov [K-S] test, $\mathrm{p}>0.99$ ), nor when either species was compared with speed of $A$. australis OR $R$. sarba (K-S test, $\mathrm{p}>0.99$ and $\mathrm{p}=0.135$, respectively); these taxa were pooled in the subsequent analysis. To compare swimming speeds, only surface-swimmers were analysed because not all taxa swam in midwater or near the bottom. The frequency distribution of swimming speeds differed among species, with $P$. auratus and $G$. tricuspidata larvae being faster swimmers than $A$. australis AND R. sarba larvae (K-S test, $0.001<\mathrm{p}<0.003)$. Larvae of $P$. auratus swam more slowly near the bottom than near the surface (Fig. 2; K-S test, $\mathrm{p}=0.001$ ). There were insufficient bottomswimming larvae of the other 3 species for a comparison of swimming speed with depth.

\section{Swimming direction}

To determine whether larvae swam in random directions once released, individual trajectories were analysed using Rayleigh's test (Batschelet 1981). The low number of observations at some sites precluded analysis of differences in orientation among sites. However, when pooled by taxon, the majority of larvae

Table 2. Number of larvae with random (R) and directed (D) swimming after release

\begin{tabular}{|c|c|c|c|c|c|}
\hline & . australis & R. sarba & $\begin{array}{l}\text { A. australis } \\
\text { OR R. sarba }\end{array}$ & P. auratus & G. tricuspidata \\
\hline & R D & R D & R D & R D & R D \\
\hline Belmont Bay & 10 & 15 & 49 & 23 & 24 \\
\hline Black Jacks Point & t $\quad 0 \quad 0$ & 34 & 44 & 11 & \\
\hline Coal Point & 02 & 14 & 215 & 10 & \\
\hline Murrays Beach & & & 11 & 01 & \\
\hline Spectacle Island & & & & 22 & 02 \\
\hline Total & 12 & 513 & 1129 & 67 & 26 \\
\hline
\end{tabular}


of each species (54 to $75 \%$, depending on species) maintained a constant swimming direction after release (Table 2).

A 2nd-order analysis (Moore's nonparametric test; Batschelet 1981) of the larval trajectories at the 2 deep sites indicates that Acanthopagrus australis and Rhabdosargus sarba larvae did not orient to the adjacent shoreline (Table 3), nor to the sun which was to the northwest during all releases.

There were insufficient data at these sites to analyse Pagrus auratus and Girella tricuspidata larvae.

\section{Swimming depth}

Larvae of all taxa often followed a steep vertical trajectory upon release, reaching and maintaining a narrow depth range of about $1 \mathrm{~m}$, often within $2 \mathrm{~min}$ (Fig. 3). However, the rate of ascent or descent varied, with some individual larvae taking over 5 min for their swimming depth to stabilise at a near-horizontal depth.

Larvae were classified as being surface or bottomoriented if they swam within $1 \mathrm{~m}$ of the surface or bottom, respectively, after their swimming depth stabilised. All others were classified as midwateroriented. Bottom swimmers maintained their position relative to the bottom and swam into the weak bottom currents, or among seagrass leaves 0.1 to $0.2 \mathrm{~m}$ (Zostera) or 0.5 to $0.8 \mathrm{~m}$ (Posidonia) in length.

Species-specific depth preferences at deep and shallow sites are summarised in Table 4. None of the Acanthopagrus australis AND Rhabdosargus sarba larvae settled, regardless of release site. They typically swam near the surface, except at the 2 deep sites (Black

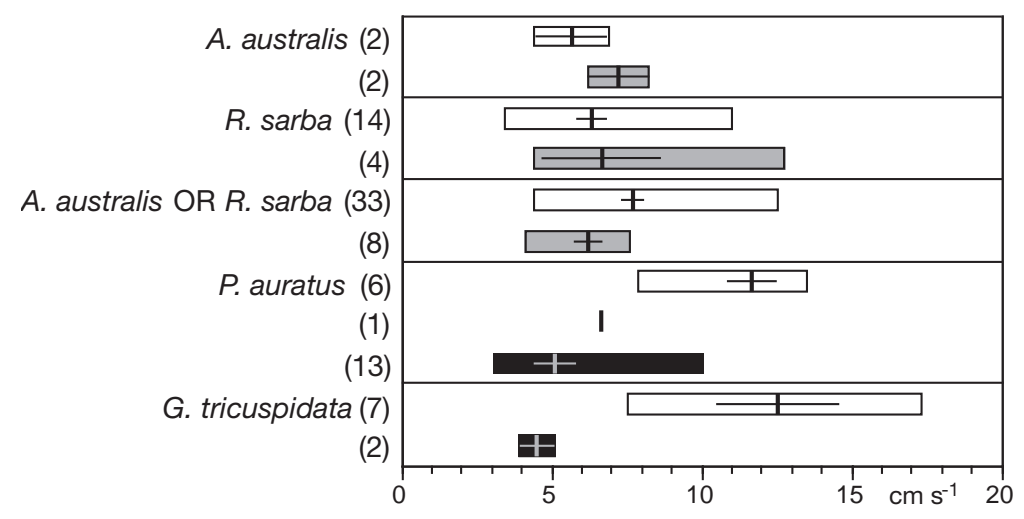

Fig. 2. Mean (vertical line), SE (horizontal line) and range (box) of average swimming speeds of late-stage fish larvae. Surface, midwater and bottom swimmers shown by white, grey and black boxes, respectively. Number of larvae in brackets. See Fig. 3 for full species names
Jacks and Coal Points, Fig. 3) where 16 of 46 A. australis AND R. sarba larvae swam in mid-water depths. Almost all surface swimmers of these 2 species stayed within the top $5 \mathrm{~cm}$ of the water column. Pagrus auratus larvae swam near the bottom except at 3 shallow sites where some larvae swam near the surface: Belmont Bay (1 of 5), Murrays Beach (1 of 9) and Spectacle Island (3 of 4). P. auratus larvae were observed settling over soft muddy bottoms at the 2 deep sites (Black Jacks and Coal Points), hovering 1 to $5 \mathrm{~cm}$ above the bottom. Where seagrass was present, $P$. auratus larvae swam near the bottom and among the sparse Zostera (Murrays Beach and Nords Wharf) or Posidonia leaves (Belmont Bay). Girella tricuspidata larvae were almost always surface swimmers. Only 2 of 13 larvae apparently settled, and both swam into dense Posidonia leaves.

\section{DISCUSSION}

The average swimming speeds recorded for the temperate larvae in the present study ranged from 6.3 to 11.2 $\mathrm{BL} \mathrm{s}^{-1}$. These speeds were intermediate between the speed of tropical reef-fish larvae (most taxa 10 to $20 \mathrm{BL} \mathrm{s}^{-1}$, range 1.1 to $33.8 \mathrm{BL} \mathrm{s}^{-1}$; Leis \& Carson-Ewart 1997) and the speed of temperate larvae (most taxa 1 to $3 \mathrm{BL} \mathrm{s}^{-1}$, some up to 5 BL s$^{-1}$; Fukuhara 1985, 1987, Blaxter 1986, Miller et al. 1988, Langdon \& Collins 2000). Lower water temperature can reduce the swimming speed of fish larvae (Fuiman \& Batty 1997). However, temperature alone does not explain the different swimming speeds reported for tropical and temperate larvae. Walleye, bass and mackerel larvae swam slower than larvae in this study at similar or higher water temperatures (Blaxter 1986).

Phylogenetic differences in the fishes from temperate and tropical regions may partially explain the differences (Leis \& McCormick 2002), but studies on larvae 

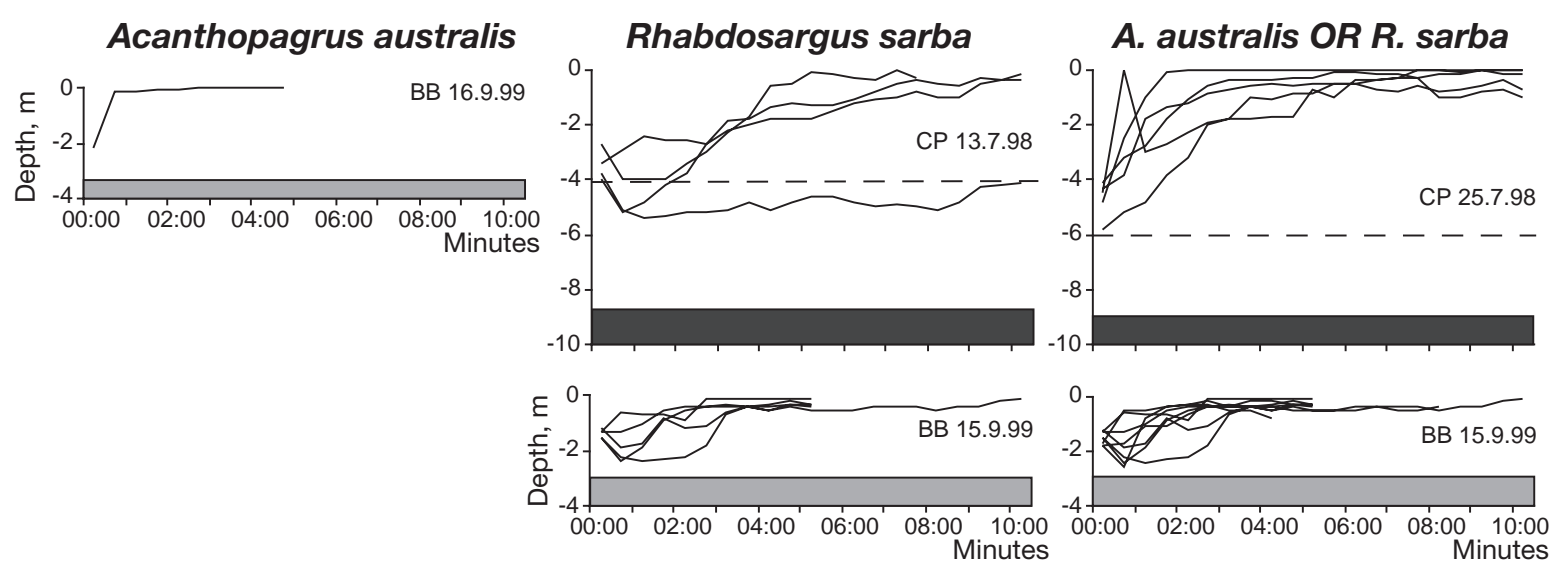

Pagrus auratus

Fig. 3. Examples of depth profiles of late-stage larvae. See Table 1 for site codes. Grey = sandy bottom; black = muddy bottom; dashed line = depth at which bottom was visible
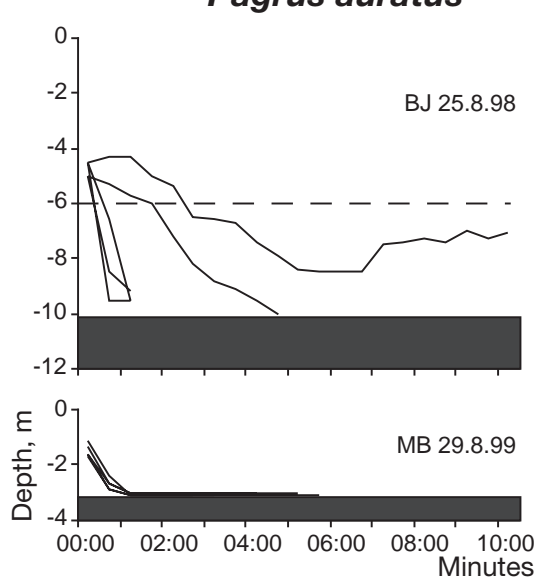

Girella tricuspidata

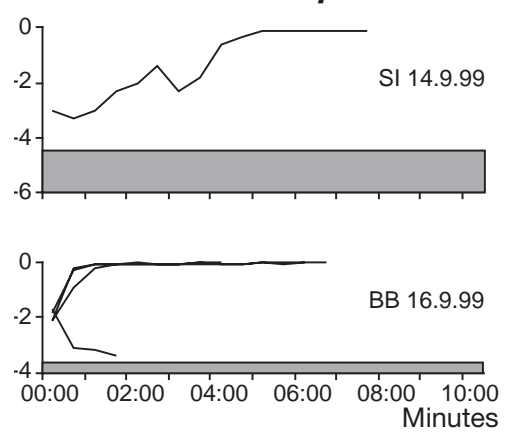

from temperate habitats (summarised in Blaxter 1986) included perciform taxa, the dominant order in the tropical studies (Leis \& Carson-Ewart 1997). It is unlikely that the differences in swimming speeds between temperate and tropical fish larvae are due to the different methods used (respectively laboratory and in situ observations; discussed by Leis \& Stobutzki 1999).

Morphology may explain the different swimming abilities (Leis \& McCormick 2002). Recently settled juveniles of a sillaginid with an elongate morphology were relatively weak swimmers and could not sustain speeds of $5 \mathrm{BL} \mathrm{s}^{-1}$ (Jenkins \& Welsford 2002). Latestage larvae and small juveniles of 5 species swam up to $10 \mathrm{BL} \mathrm{s}^{-1}$ in a swimming chamber set at a flow rate of
$13.5 \mathrm{~cm} \mathrm{~s}^{-1}$ (Dudley 2000). Swimming endurance increased with size in the carangid Trachurus sp., and in 4 other species when they were pooled. The most elongate of the 5 species, the mullid Upeneichthys lineatus, swam for a shorter time for its size compared with the other 4, deeper-bodied species.

Similar body morphology (with respect to propulsive area; sensu Fisher et al. 2000) and size of late larvae of Acanthopagrus australis and Rhabdosargus sarba (Miskiewicz \& Neira 1998) and some tropical apogonids (Kojima 1988, Leis \& Rennis 2000) may be responsible for their similar swimming speeds (Leis \& CarsonEwart 1997). Pagrus auratus and Girella tricuspidata larvae (Miskiewicz \& Neira 1998, Miskiewicz \& Trnski

Table 4. Number of larvae with surface, midwater or bottom orientation at deep (BJ, CP) and shallow (BB, MB, NW, SI) sites

\begin{tabular}{|c|c|c|c|c|c|c|c|c|c|c|}
\hline & \multicolumn{2}{|c|}{ A. australis } & \multicolumn{2}{|c|}{ R. sarba } & \multicolumn{2}{|c|}{ A. australis OR R. sarba } & \multicolumn{2}{|c|}{ P. auratus } & \multicolumn{2}{|c|}{ G. tricuspidata } \\
\hline & Deep & Shallow & Deep & Shallow & Deep & Shallow & Deep & Shallow & Deep & Shallow \\
\hline Surface & 1 & 1 & 8 & 6 & 21 & 10 & & 5 & & 11 \\
\hline Midwater & 2 & & 4 & & 10 & & 1 & & & \\
\hline Bottom & & & & & & & 7 & 14 & & 2 \\
\hline
\end{tabular}


1998) are morphologically similar to some tropical pomacentrids (Kavanagh et al. 2000), and they have similar swimming speeds (Leis \& Carson-Ewart 1997). In both cases the temperate species are at the lower range of speeds achieved by their morphologically similar tropical counterparts, but the general relationship confirms recent findings of a strong correlation between swimming ability and propulsive area (Fisher et al. 2000).

Flood-tide flows through Swansea Channel can be more than an order of magnitude faster than the swimming speeds of larvae (Trnski 2001). However, currents become slower as the water enters Lake Macquarie (AWACS 1995). The 4 species of larvae in the present study have the swimming capability to enter the slow convergence currents and swim into Lake Macquarie. Even at swimming speeds slower than those recorded here, another temperate Australian species could modify its displacement compared with ambient currents (Jenkins \& Welsford 2002, Hindell et al. unpubl.).

The larvae were presumably behaving normally while being followed, as they were observed feeding, foraging and excreting, and also reacting to potential predators by stopping or altering their trajectory and even swimming toward the diver for shelter. Similarly, the larvae swam evasively (faster and at erratic speed, orientation and depth) when pursued by the diver to collect voucher specimens. The speed of the larvae being observed was not near the limit of their ability, except immediately after release when some fish briefly displayed burst swimming. Standard errors of swimming speeds were relatively narrow for each species, suggesting that their behaviour was not erratic. Depth selection by Acanthopagrus australis and Rhabdosargus sarba varied with depth of release site; since their surface swimming was not consistent among shallow and deep sites, this does not appear to be an escape response to the divers. The tendency to swim in a nonrandom direction may be an attempt to swim away from divers. However, once Pagrus auratus larvae settled near a bottom, they oriented to the current and held station regardless of the diver orientation. The combination of these observations indicates that larvae behave normally, a conclusion reached by other in situ observers (Leis \& Carson-Ewart 1997).

\section{Behaviour of species settling in seagrass}

A constant swimming orientation is advantageous for larvae seeking shallow settlement habitat in Lake Macquarie, since settlement habitat occurs around the entire margin of the lake. If larvae of the surfaceoriented species (Acanthopagrus australis, Rhabdosar- gus sarba, Girella tricuspidata) delivered into the estuary by the strong currents of Swansea Channel randomly spread from their arrival point at the junction of the channel and lake, $>50 \%$ would be within $3 \mathrm{~km}$, and $>95 \%$ would be within $6 \mathrm{~km}$ of a shoreline and a seagrass bed. At the swimming speeds recorded here, it would take settlement-stage larvae 13 to $26 \mathrm{~h}$ to swim $6 \mathrm{~km}$. Based on laboratory studies of other species (Stobutzki \& Bellwood 1997, Dudley 2000), swimming durations of $24 \mathrm{~h}$ may be feasible for these 3 species. Wind-driven surface currents, which at moderate wind exceed larval swimming speeds, could further assist their arrival to seagrass nurseries. Kinoshita \& Tanaka (1990) proposed a similar mode of transport in A. schlegeli, but invoked surface tidal currents as the mechanism.

Successful settlement to seagrass nurseries would be enhanced if there were a physical cue to aid orientation. There was no evidence of orientation to shore in Acanthopagrus australis and Rhabdosargus sarba larvae. This contrasts with larvae of coral reef fishes that do orient to adjacent reefs (Leis et al. 1996, Stobutzki \& Bellwood 1998). Solar orientation influences swimming direction in some tropical pomacentrid larvae (J. M. Leis pers. comm.), but there was no evidence of solar orientation in the present study despite the consistent afternoon release of larvae when the sun was in a northwesterly direction. However, given that settlement habitat is available in all directions once larvae enter Lake Macquarie, there would be limited advantage of orienting to the shore or the sun.

All Acanthopagrus australis and Rhabdosargus sarba larvae were surface-oriented unless they were released over deep sites, where some larvae swam in mid-water depths. The bottom was not visible to the divers, nor presumably to the larvae, at these deep sites. Thus, visual cues appear to modify their behaviour. Similarly, the behaviour of coral reef fish larvae is modified in sight of a reef compared to observations of larvae in open water (Leis \& Carson-Ewart 1998, 1999).

Acanthopagrus australis and Rhabdosargus sarba released in sight of seagrass, a suitable nursery, were not observed to settle despite being competent to do so, based on size and morphological development. The larvae may prefer to settle at night; or remain near the surface until they reach very shallow seagrass close to shore, to avoid predation; or they may not be able to perceive the bottom as divers do; or they may not have received appropriate settlement cues.

\section{Behaviour of Pagrus auratus}

Pagrus auratus larvae almost always settled, and it would be expected that high abundances of recently 
settled $P$. auratus juveniles occur on the bottom of Lake Macquarie near the junction with Swansea Channel. In support of this, small $P$. auratus juveniles are found in deep, soft mud in Port Phillip Bay (Hamer et al. 1998). Three of the 4 larvae released at Spectacle Island were driven by a rapid current over a shallow $(0.6$ to $1.0 \mathrm{~m})$ sand bank. The site was thus unfavourable for settlement, and the larvae did not attempt to settle. The single larva that immediately swam deep at this site avoided the strong surface current and managed to settle over sand adjacent to a Posidonia margin at a depth of approximately $4 \mathrm{~m}$.

\section{Summary}

The larvae of the 4 species studied are strong swimmers and demonstrate complex behaviour as they approach settlement. This includes preferentially swimming in surface waters for Acanthopagrus australis, Rhabdosargus sarba and Girella tricuspidata, where surface currents can assist transport to a nursery habitat. Directed swimming orientation in these 3 species may also provide an advantage in locating settlement habitat in mostly enclosed estuaries. Swimming to the bottom in Pagrus auratus larvae is consistent with their preferred settlement habitat of deep mud. All 4 species actively modify their dispersal once in Lake Macquarie. Additional studies are required to determine settlement success and location in fishes that use estuaries as juvenile nurseries.

Acknowledgements. R. Alquezar, D. Booth, T. Compton, E. Corfield, S. Cowan, T. Dempster, W. Fitness, A. Hay, P. Howe, M. Lockett, J. Plaza, J. Spyrakis, J. Upston and R. Young assisted in the field; thank you all. D. Allsop of Manly Hydraulics Laboratory arranged for the loan of the drogues. Staff at the Royal Australian Volunteer Coastal Patrol, Pelican, recorded wind data. Comments by D. Booth, J. Hindell, $\mathrm{J}$. Leis, and 4 anonymous reviewers improved the manuscript. J. Hindell, G. Jenkins and J. Leis provided unpublished data or manuscripts. This research was supported by an Australian Postgraduate Award (Industry) AP96055 from the Department of Employment, Education and Training, Lake Macquarie Research Grant 96/97-4 from the Lake Macquarie City Council, the Department of Environmental Sciences, University of Technology, Sydney, and the Australian Museum. Animal experimentation was conducted under RNSH/UTS protocol number 9808-041A.

\section{LITERATURE CITED}

Able K W, Fahay MP (1998) The first year in the life of estuarine fishes in the Middle Atlantic Bight. Rutgers University Press, New Brunswick, NJ

Armsworth PR (2000) Modelling the swimming response of late stage reef fish to different stimuli. Mar Ecol Prog Ser 195:231-247
AWACS (1995) Lake Macquarie Estuary Process Study, 2 Vol. Australian Water and Coastal Studies Report 94/25

Azeta M, Ikemoto R, Azuma M (1980) Distribution and growth of demersal 0-age red sea bream, Pagrus major, in Shinjiki Bay. Bull Seikai Reg Fish Res Lab 54:259-278

Batschelet E (1981) Circular statistics in biology. Academic Press, London

Blaxter JHS (1986) Development of sense organs and behaviour of teleost larvae with special reference to feeding and predator avoidance. Trans Am Fish Soc 115:98-114

Breitburg DL, Palmer, MA, Loher, T (1995) Larval distributions and the spatial patterns of settlement of an oyster reef fish: responses to flow and structure. Mar Ecol Prog Ser 125:45-60

Dudley B, Tolimieri N, Montgomery J (2000) Swimming ability of the larvae of some reef fishes from New Zealand waters. Mar Freshw Res 51:783-787

Fisher R, Bellwood DR, Job SD (2000) Development of swimming abilities in reef fish larvae. Mar Ecol Prog Ser 202: 163-173

Forward RB Jr, Reinsel KA, Peters DS, Tankersley RA and 5 others (1999) Transport of fish larvae through a tidal inlet. Fish Oceanogr 8(Suppl 2):153-172

Francis MP (1995) Spatial and seasonal variation in the abundance of juvenile snapper (Pagrus auratus) in the northwestern Hauraki Gulf. NZ J Mar Freshw Res 29:565-579

Fuiman LA, Batty RS (1997) What a drag it is getting cold: partitioning the physical and physiological effects of temperature on fish swimming. J Exp Biol 200:1745-1755

Fukuhara O (1985) Functional morphology and behaviour of early life stages of red sea bream. Bull Jpn Soc Sci Fish 51: 731-743

Fukuhara O (1987) Larval development and behaviour in early life stages of black sea bream reared in the laboratory. Nippon Suisan Gakkaishi 53:371-379

Hamer PA, Jenkins GP, Welsford D (1998) Sampling of newlysettled snapper, Pagrus auratus, and identification of preferred habitats in Port Phillip Bay-a pilot study. Final Report to Fish Res Develop Corp, Project 96/279. Mar Freshw Resources Inst, Victoria

Hannan JC, Williams RJ (1998) Recruitment of juvenile marine fishes to seagrass habitat in a temperate Australian estuary. Estuaries 21:29-51

Jenkins GP, Black KP (1994) Temporal variability in settlement of a coastal fish (Sillaginodes punctata) determined by lowfrequency hydrodynamics. Limnol Oceanogr 39:1744-1754

Jenkins GP, Welsford DC (2002) The swimming abilities of recently settled post-larvae of Sillaginodes punctata. J Fish Biol 60:1043-1050

Jenkins GP, Black KP, Wheatley MJ, Hatton DN (1997) Temporal and spatial variability in recruitment of a temperate, seagrass-associated fish is largely determined by physical processes in the pre- and post-settlement phases. Mar Ecol Prog Ser 148:25-35

Jenkins GP, Black KP, Keough MJ (1999) The role of passive transport and the influence of vertical migration on the pre-settlement distribution of a temperate, demersal fish: numerical model predictions compared with field sampling. Mar Ecol Prog Ser 184:259-271

Kavanagh KD, Leis JM, Rennis DS (2000) Pomacentridae (Damselfishes). In: Leis JM, Carson-Ewart BM (eds) The larvae of Indo-Pacific coastal fishes: an identification guide to marine fish larvae. Fauna Malesiana Handbook 2. Brill, Leiden, p 526-535

King RJ (1986) Aquatic angiosperms in coastal saline lagoons of New South Wales. I. The vegetation of Lake Macquarie. Proc Linn Soc NSW 109:11-23 
Kinoshita I, Tanaka M (1990) Differentiated spatial distribution of larvae and juveniles of the two sparids, red and black sea bream, in Shijiki Bay. Nippon Suisan Gakkaishi 56:1807-1813

Kojima J (1988) Apogonidae. In: Okiyama M (ed) An atlas of the early stage fishes in Japan. Tokai University Press, Tokyo, p 431-450

Langdon SA, Collins AL (2000) Quantification of the maximal swimming performance of Australian glass eels, Anguilla australis and Anguilla reinhardtii, using a hydraulic flume swimming chamber. NZ J Mar Freshw Res 34:629-636

Laegdsgaard P, Johnson CR (1995) Mangrove habitats as nurseries: unique assemblages of juvenile fish in subtropical mangroves in eastern Australia. Mar Ecol Prog Ser 126:67-81

Leis JM, Carson-Ewart BM (1997) In situ swimming speeds of the late pelagic larvae of some Indo-Pacific coral-reef fishes. Mar Ecol Prog Ser 159:165-174

Leis JM, Carson-Ewart BM (1998) Complex behaviour by coral-reef fish larvae in open-water and near-reef pelagic environments. Environ Biol Fishes 53:259-266

Leis JM, Carson-Ewart BM (1999) In situ swimming and settlement behaviour of larvae of an Indo-Pacific coralreef fish, the coral trout Plectropomus leopardus (Pisces: Serranidae). Mar Biol 134:51-64

Leis JM, Carson-Ewart BM (2000) The larvae of Indo-Pacific coastal fishes: an identification guide to marine fish larvae. Fauna Malesiana Handbook 2. Brill, Leiden

Leis JM, McCormick MI (2002) The biology, behaviour and ecology of the pelagic, larval stage of coral-reef fishes. In: Sale PF (ed) Coral reef fishes: dynamics and diversity in a complex ecosystem. Academic Press, San Diego, p 171-199

Leis JM, Rennis DS (2000) Apogonidae (Cardinalfishes). In: Leis JM, Carson-Ewart BM (eds) The larvae of IndoPacific coastal fishes: an identification guide to marine fish larvae. Fauna Malesiana Handbook 2. Brill, Leiden, p 273-279

Leis JM, Stobutzki IC (1999) Swimming performance of late pelagic larvae of coral-reef fishes: in situ and laboratorybased measurements. Proc 5th Indo-Pacific Fish Conf, Noumea, New Caledonia, 575-583

Leis JM, Sweatman HPA, Reader SE (1996) What the pelagic stages of coral reef fishes are doing out in blue water: daytime field observations of larval behavioural capabilities. Mar Freshw Res 47:401-411

MHL (1996) Swansea Channel and Lake Macquarie Data Collection March-June 1996. Manly Hydraulics Laboratory Report 770. Department of Public Works and Services, Manly Vale, NSW

Miller TJ, Crowder LB, Rice JA, Marschall EA (1988) Larval size and recruitment mechanisms in fishes: toward a conceptual framework. Can J Fish Aquat Sci 45:1657-1670

Miskiewicz AG, Neira FJ (1998) Sparidae: breams and snappers. In: Neira FJ, Miskiewicz AG, Trnski T (eds) Larvae of temperate Australian fishes: laboratory guide for larval fish identification. University of Western Australia Press, Nedlands, WA, p 306-315

Miskiewicz AG, Trnski T (1998) Girellidae: blackfishes, lud-

Editorial responsibility: Otto Kinne (Editor),

Oldendorf/Luhe, Germany erick. In: Neira FJ, Miskiewicz AG, Trnski T (eds) Larvae of temperate Australian fishes: laboratory guide for larval fish identification. University of Western Australia Press, Nedlands, WA p 232-235

Power JH (1984) Advection, diffusion, and drift migrations of larval fish. In: McCleave JD, Arnold GP, Dodson JJ, Neill WH (eds) Mechanisms of migration in fishes. Plenum Press, New York

Roy PS, Peat C (1975) Bathymetry and bottom sediments of Lake Macquarie. Rec Geol Survey NSW 17:53-64

Shanks AL (1985) Behavioural basis of internal-wave-induced shoreward transport of megalopae of the crab Pachygrapsus crassipes. Mar Ecol Prog Ser 24:289-295

Shanks AL (1995) Orientated swimming by megalopae of several eastern North Pacific crab species and its potential role in their onshore migration. J Exp Mar Biol Ecol 186: $1-16$

SPCC (1981) The ecology of fish in Botany Bay — biology of commercially and recreationally valuable species. State Pollution Control Commission, Environmental Control Study of Botany Bay BBS 23B, Sydney

Stobutzki IC (1998) Interspecific variation in sustained swimming ability of late pelagic stage reef fish from two families (Pomacentridae and Chaetodontidae). Coral Reefs 17: 111-119

Stobutzki IC, Bellwood DR (1994) An analysis of the sustained swimming abilities of pre- and post-settlement coral reef fishes. J Exp Mar Biol Ecol 175:275-286

Stobutzki IC, Bellwood DR (1997) Sustained swimming abilities of the late pelagic stages of coral reef fishes. Mar Ecol Prog Ser 149:35-41

Stobutzki IC, Bellwood DR (1998) Nocturnal orientation to reefs by late pelagic stage coral reef fishes. Coral Reefs 17: 103-110

Tolimieri N, Jeffs A, Montgomery JC (2000) Ambient sound as a cue for navigation by the pelagic larvae of reef fishes. Mar Ecol Prog Ser 207:219-224

Trnski T (2001) Diel and tidal abundance of fish larvae in a barrier estuary channel in New South Wales. Mar Freshw Res 52:995-1006

WA (1998) Map of Lake Macquarie. Waterways Authority of New South Wales

Wardle CS (1975) Limit of fish swimming speed. Nature 255: 725-727

Werner FE, Blanton BO, Quinlan JA, Luettich Jr RA (1999) Physical oceanography of the North Carolina continental shelf during the fall and winter seasons: implications for the transport of larval menhaden. Fish Oceanogr 8(Suppl2):7-21

Wieser W, Kaufmann R (1998) A note on interactions between temperature, viscosity, body size and swimming energetics in fish larvae. J Exp Biol 201:1369-1372

Wolanski E, Doherty PJ, Carleton JH (1997) Directional swimming of fish larvae determines connectivity of fish populations on the Great Barrier Reef. Naturwissenschaften 84: 262-268

Zar JH (1996) Biostatistical analysis, 3rd edn. Prentice Hall, Upper Saddle River, NJ

Submitted: December 3, 2001; Accepted: July 4, 2002

Proofs received from author(s): October 9, 2002 